\title{
Ozonation control and effects of ozone on water quality in recirculating aquaculture systems
}

Spiliotopoulou, Aikaterini; Rojas-Tirado, Paula Andrea; Chetri, Ravi K.; Kaarsholm, Kamilla Marie Speht; Martin, Richard; Pedersen, Per Bovbjerg; Pedersen, Lars-Flemming; Andersen, Henrik Rasmus

Published in:

Water Research

Link to article, DOI:

10.1016/j.watres.2018.01.032

Publication date:

2018

Document Version

Peer reviewed version

Link back to DTU Orbit

Citation $(A P A)$ :

Spiliotopoulou, A., Rojas-Tirado, P. A., Chetri, R. K., Kaarsholm, K. M. S., Martin, R., Pedersen, P. B., Pedersen, L-F., \& Andersen, H. R. (2018). Ozonation control and effects of ozone on water quality in recirculating aquaculture systems. Water Research, 133, 289-298. https://doi.org/10.1016/j.watres.2018.01.032

\section{General rights}

Copyright and moral rights for the publications made accessible in the public portal are retained by the authors and/or other copyright owners and it is a condition of accessing publications that users recognise and abide by the legal requirements associated with these rights.

- Users may download and print one copy of any publication from the public portal for the purpose of private study or research.

- You may not further distribute the material or use it for any profit-making activity or commercial gain

- You may freely distribute the URL identifying the publication in the public portal 


\section{Accepted Manuscript}

Ozonation control and effects of ozone on water quality in recirculating aquaculture systems

Aikaterini Spiliotopoulou, Paula Rojas-Tirado, Ravi K. Chetri, Kamilla M.S. Kaarsholm, Richard Martin, Per B. Pedersen, Lars-Flemming Pedersen, Henrik R. Andersen

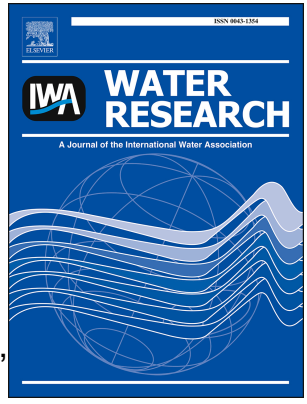

PII:

S0043-1354(18)30046-0

DOI:

10.1016/j.watres.2018.01.032

Reference: WR 13511

To appear in: Water Research

Received Date: 31 October 2017

Revised Date: 12 January 2018

Accepted Date: 13 January 2018

Please cite this article as: Spiliotopoulou, A., Rojas-Tirado, P., Chetri, R.K., Kaarsholm, K.M.S., Martin, R., Pedersen, P.B., Pedersen, L.-F., Andersen, H.R., Ozonation control and effects of ozone on water quality in recirculating aquaculture systems, Water Research (2018), doi: 10.1016/j.watres.2018.01.032.

This is a PDF file of an unedited manuscript that has been accepted for publication. As a service to our customers we are providing this early version of the manuscript. The manuscript will undergo copyediting, typesetting, and review of the resulting proof before it is published in its final form. Please note that during the production process errors may be discovered which could affect the content, and all legal disclaimers that apply to the journal pertain. 


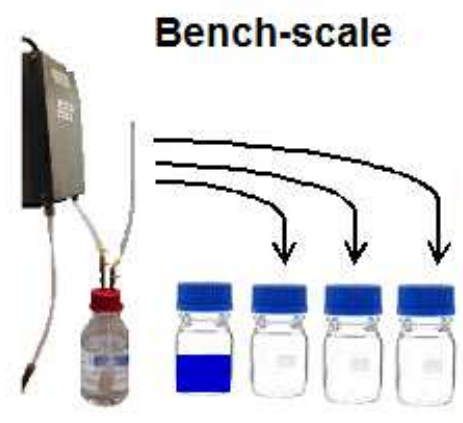

$1 \mathrm{~mL} 5 \mathrm{~mL} 15 \mathrm{~mL}$
Predicted

$\mathrm{O}_{3}$ dosages

are applied in pilot-RAS

\section{Pilot-scale}

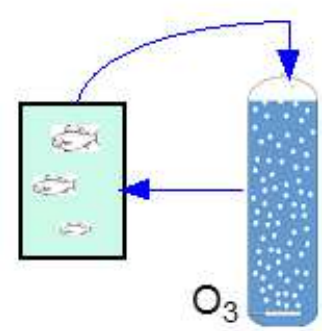

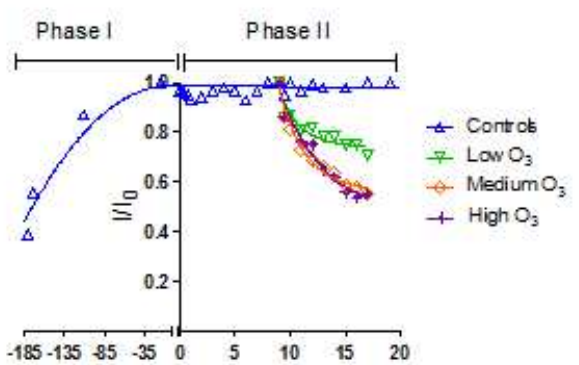


3 Aikaterini Spiliotopoulou ${ }^{1,2}$, Paula Rojas-Tirado ${ }^{3}$, Ravi K. Chetri, Kamilla M.S.

$4 \quad$ Kaarsholm ${ }^{1}$, Richard Martin ${ }^{4}$, Per B. Pedersen ${ }^{3}$, Lars-Flemming Pedersen ${ }^{3}$, Henrik R. Andersen ${ }^{1 *}$

5

$6{ }^{1}$ Department of Environmental Engineering, Technical University of Denmark, Bygningstorvet 115, 2800 Kongens Lyngby,

7 Denmark

$8 \quad{ }^{2}$ OxyGuard International A/S, Farum Gydevej 64, 3520 Farum, Denmark

$9 \quad{ }^{3}$ National Institute of Aquatic Resources, Technical University of Denmark, NordsøenForskerpark, Postboks 101, 9850 Hirtshals

$10{ }^{4}$ Water ApS, Farum Gydevej 64, 3520 Farum, Denmark

11 *Corresponding author: hran@env.dtu.dk 


\section{Abstract}

To address the undesired effect of chemotherapeutants in aquaculture, ozone has been suggested as an alternative to improve water quality. To ensure safe and robust treatment, it is vital to define the ozone demand and ozone kinetics of the specific water matrix to avoid ozone overdose. Different ozone dosages were applied to water in freshwater recirculating aquaculture systems (RAS). Experiments were performed to investigate ozone kinetics and demand, and to evaluate the effects on the water quality, particularly in relation to fluorescent organic matter. This study aimed at predicting a suitable ozone dosage for water treatment based on daily ozone demand via laboratory studies. These ozone dosages will be eventually applied and maintained at these levels in pilot-scale RAS to verify predictions. Selected water quality parameters were measured, including natural fluorescence and organic compound concentration changes during ozonation. Ozone reactions were described by first order kinetics. Organic matter, assessed as chemical oxygen demand and fluorescence, decreased by $25 \%\left(\right.$ low $\mathrm{O}_{3}$ ), $30 \%$ (middle $\mathrm{O}_{3}$ ) and $53 \%$ (high $\mathrm{O}_{3}$ ), while water transmittance improved by $15 \%$ over an 8 -day period. No fish mortality was observed. Overall, this study confirms that ozone can improve RAS water quality, provides a better understanding of the ozone decay mechanisms that can be used to define further safe ozone treatment margins, and that fluorescence could be used as a monitoring tool to control ozone. This study might be used as a tool to design ozone systems for full-scale RAS by analysing water sample from the specific RAS in the laboratory.

\section{Keywords}

Ozone, water quality, RAS, pilot-scale, laboratory study, fluorescence 


\section{Abbreviations}

36 Recirculating aquaculture system (RAS), Dissolved organic carbon (DOC), Non-volatile organic 37 carbon (NVOC), Ultraviolet absorption (UVA), Ultraviolet transmittance (UVT), Total ammonium 38 nitrogen (TAN), Oxidation reduction potential (ORP). 


\section{Introduction}

Land-based recirculating aquaculture systems (RAS) have become increasingly important, as they consume less water per kilogram of fish produced, ensure stable conditions and allow solids removal and effluent treatment, among others (Piedrahita, 2003). In such systems, organic and inorganic compounds accumulate that potentially deteriorate water quality and create favourable conditions for opportunistic bacteria. Various chemicals, namely formalin, hydrogen peroxide, peracetic acid and sodium chloride, are used to control microbial profusions and prevent disease outbreaks (Noble \& Summerfelt, 1996; Pedersen et al., 2010; Pedersen \& Pedersen, 2012; Pedersen et al., 2013; Verner-Jeffreys, 2015). However, high concentrations of chemotherapeutants might impair biofilter performance, affect fish welfare, jeopardize worker safety and place the ecosystem at risk when non-degraded residuals are released into nearby aquatic sources (Hohreiter \& Rigg, 2001; Masters, 2004; Wooster et al., 2005; Pedersen et al., 2010).

To address the need for environmentally friendly disinfectants, ozone has been widely implemented as a supplementary water treatment technology (Von Gunten, 2003, Tsolaki \& Diamadopoulos, 2010; Hansen et al., 2010; Hansen et al., 2016; Hansen, et al., 2016). It has been proven to enhance water quality, since it oxidises various deteriorating agents such as carbon-based compounds and nitrite, natural organic matter (NOM), chemical oxygen demand (COD), colour and suspended solids (Summerfelt \& Hochheimer, 1997; Summerfelt et al., 2009; Davidson et al., 2011). It has been also reported to reduce geosmin, bacteria and miscellaneous fish pathogens (Bullock et al., 1997; Tango \& Gagnon, 2003; Summerfeltet al., 2009), resulting in improved growth (Good et al., 2011) while enriching the water with oxygen, which is formed during ozone degradation.

Although ozonation has been applied for years in aquaculture, there is still a knowledge gap regarding how to predict the optimal ozone dosage for a system, known as "ozone demand." In a non-meticulously designed system, residual ozone (an over-dose) will reach culture tanks, thereby 
63

potentially affecting farmed species (Bullock et al., 1997; Summerfelt et al., 2004; Davidson et al., 2011; Powell \& Scolding, 2016), while electricity consequently is wasted, having a significant monetary impact. The control of dissolved ozone is a major issue. Currently, there are several companies which supply dissolved ozone sensors which are either expensive and somewhat unreliable or not specific (Bullock et al., 1997). Dissolved ozone probes will not tell the ozone dosage to the water as the ozone is consumed very fast by reaction with dissolved organic matter in the low dosages applied in aquaculture and they also do not detect changes in ozone demand of the system.

A widely used method to control the delivery of ozone into water is the oxidation reduction potential (ORP; Bullock et al., 1997; Summerfelt et al. 1997; Summerfelt et al. 2009; Davidson et al., 2011; Li et al. 2014; Powell \& Scolding, 2016), which measures a balance between the concentrations and willingness of substances in solution to give up or receive electrons. The ORP sensor is placed in the RAS system at a point where ozone is completely consumed downstream of the ozone treatment as free ozone damage ORP sensors (Bullock et al., 1997). In fully aerated aquaculture water, the dominant oxidant will be oxygen at the equilibrium concentration defined by the atmosphere and therefor the reading of the ORP will be an unspecific measure of the reducing solutes. As ozone quickly oxidised these reducing species the effect of ozone is measured indirectly but not specifically by the difference in the ORP reading before and after the ozone treatment. Wenk et al. (2013) suggested that mediated electrochemical oxidation (MEO) could be used in water treatment applications to determine the DOM oxidation in chemical oxidation processes since the electron donating capacity was highly sensitive to DOM changes. Ozone applied in wastewater showed a correlation with changes in UV absorbance at $254 \mathrm{~nm}$ (Bahr et al., 2007; Nanaboina \& Korshin, 2010; Wenk et al., 2013) or at $272 \mathrm{~nm}$ (Hansen, et al., 2010). Nevertheless, a recent study 
set the basis for a highly sensitive and accurate method to control ozone, based on the natural fluorescence removal of organic matter upon ozonation in an RAS (Spiliotopoulou et al., 2017).

There is therefore a need for a practical study to investigate ozone demand and kinetics in actual RAS water. The added ozone should be suitable to ensure a realistic "safety window" that is system-specific, does not exceed system demand and is nonetheless effective in promoting hygiene and water quality (Muller \& Milton, 2012).

This study aims to reveal a more direct approach to describe the removal of carbon-based compounds and the control of ozone dosages in RAS. This approach could be also used to predict the required ozone dosage in RAS based solely on water quality parameters analysed in the laboratory. To achieve this aim, water samples were collected from a pilot-scale system and then, subjected to ozonation. The project objectives were i) to investigate the probability of predicting the effects of continuous ozonation in pilot-scale RAS on water quality (laboratory-scale experiments), ii) to determine the optimal ozone dosage in freshwater pilot-scale RAS, to ensure improved water quality without compromising fish health, and iii) to analyse the effects of different ozone dosages on resulting water quality parameters, including by-product formation and toxicity risk and iv) to investigate fluorescence sensitivity in ozonated RAS.

\section{Material and methods}

\subsection{Reagents}

All chemicals used in this study were purchased from Sigma Aldrich Denmark ApS and used as received. 


\subsection{Sample management}

Samples were collected from the pump sump of the pilot RAS by siphoning. Depending on the pending analysis (Table S1), the samples were filtered according to standard operational procedures and stored at either $4^{\circ} \mathrm{C}$, when the analysis occurred the same day, or at $-20^{\circ} \mathrm{C}$, when samples were analysed at the end of the experiment.

\subsection{Quantification}

\subsubsection{Ozonation}

The laboratory ozone set-up was based on a $20 \mathrm{~g} / \mathrm{h}$ ozone generator from $\mathrm{O}_{3}$-Technology $\mathrm{AB}$ (Vellinge, Sweden), supplied with dry oxygen gas. The generated ozone was dispersed through a diffuser in a pressurised collection bottle containing ultra-pure water, to create the ozone stock solution. To increase ozone solubility further, the bottle was submerged in an ice bath, while a manometer and a valve were placed after the collection bottle at a pressure of 1.2 barG. Ozone concentration in the stock solution ranged between 70 and $110 \mathrm{mg} / \mathrm{L}$. The pilot ozonation set-up was based on a $500 \mathrm{mg} / \mathrm{h}$ generator (Sander, Germany) and supplied with dry air (Flairmo ApS, Denmark).

\subsubsection{Determination of ozone concentrations}

The concentration of ozone in both the aqueous and the gaseous phases was determined daily. Ozone concentration in the water was determined utilising the indigo method (Bader \& Hoigné, 1981), while the absorbance of the unreacted indigotrisulphonate was measured at $600 \mathrm{~nm}$ with a spectrophotometer (Hach Lange). Ozone concentration was determined by comparing the absorbance of a blank to the sample, and by using $\Delta \mathrm{A}=-20000 \mathrm{l} /(\mathrm{cm}$ mol ozone added per $\mathrm{L})$. 
130 Ozone gas concentration was determined with a flow cell connected to a spectrophotometer, 131 measured at $254 \mathrm{~nm}$ (Hansen et al., 2010) utilising the Beer-Lamberts law (Eq.1).

$\boldsymbol{C}_{\boldsymbol{O}_{3}}=\frac{A}{l \cdot \varepsilon} \cdot \boldsymbol{M}_{\boldsymbol{w}, \boldsymbol{O}_{3}} \quad$ Equation 1

133 Where $\mathrm{A}$ is the absorbance of gas, 1 is the light path in $\mathrm{cm}(1=1.00 \mathrm{~cm}), \varepsilon$ is the ozone molar 134 absorption coefficient at $254 \mathrm{~nm}(\varepsilon=3000 \mathrm{NL} /(\mathrm{mol} \cdot \mathrm{cm}))$ and $\mathrm{M}_{\mathrm{w}, \mathrm{O} 3}$ is the molar mass of ozone $135\left(\mathrm{M}_{\mathrm{w}, \mathrm{O} 3}=48 \mathrm{~g} / \mathrm{mol}\right)$.

\subsubsection{Determination of ozone demand}

138 Fluorescence spectroscopy was used to determine indirectly the dosage of ozone delivered into 139 water, as described by Spiliotopoulou et al. (2017) utilising a fluorimeter (Cary Eclipse, Varian). 140 Two excitation/emission wavelength transitions were included in this study, namely Ex275/Em340 141 and Ex3355/Em450, representing protein and humic-like substances contained in water, 142 respectively (Hudson et al., 2007). Miscellaneous wavelength transitions were studied and can be 143 found in the Supporting Information (SI 3.1).

\subsubsection{UV absorbance (UVA)}

146 Water clarity was determined in terms of UVA and/or UV transmittance (UVT\%), measuring 147 directly the absorbance of water samples at $254 \mathrm{~nm}$ using a $10 \mathrm{~mm}$ quartz cuvette.

$148 \quad U V A=A_{254 n m}=-\log \left(I / I_{0}\right) \quad$ Equation 2

$149 \% U V T=100 \times 10^{-U V A} \quad$ Equation 3

150 Where $\mathrm{I}=$ light intensity at the detector (light out) and $\mathrm{I}_{0}=$ intensity of the light incident before the 151 sample (light in). 


\subsubsection{Non-volatile organic carbon (NVOC) determination}

A Shimadzu ASI-V UVC/Persulphate analyser quantified the non-volatile organic carbon (NVOC) of the filtered samples $(0.45 \mu \mathrm{m})$. The injected sample volume was $3.00 \mathrm{~mL}$ and a calibration curve with potassium hydrogen phthalate standards from 50 to $2000 \mu \mathrm{g} / \mathrm{L}$ was determined $\left(\mathrm{R}^{2}=0.9994\right)$ with a quantification limit set at $50 \mu \mathrm{g} / \mathrm{L}$.

\subsubsection{Chemical Oxygen Demand (COD)}

Total (raw samples), dissolved (filtered with $0.45 \mu \mathrm{m})$ and particulate $\left(\mathrm{COD}_{\mathrm{PART}}=\mathrm{COD}_{\mathrm{TOT}}-\mathrm{COD}_{\mathrm{DIS}}\right)$ chemical oxygen demand (COD) was determined by utilising test-kits (LCK 1414, Hack Lange, Germany) according to ISO standards (ISO, 2012).

\subsubsection{Nitrogen- and phosphorous-based compounds}

Samples were filtered $(0.22 \mu \mathrm{m})$ and analysed for total ammonia nitrogen (TAN), nitrite $\mathrm{NO}_{2}^{-}-\mathrm{N}$, nitrate $\mathrm{NO}_{3}{ }^{-}-\mathrm{N}$ and ortho-phosphate (dissolved phosphorous, P). TAN was determined colourimetrically, accordingly to Danish standards (DS 224, 1975), while the remaining parameters were analysed by utilising the auto-sampler $\mathrm{San}^{++}$, SKALAR.

\subsubsection{Water parameters}

Water temperature, $\mathrm{pH}$ and dissolved oxygen (DO) were determined by probes (Hack HQ40d instrument, Hack Lange, Germany), while reduction oxidation potential (REDOX) and DO were monitored by a Pacific unit (Oxyguard International AS, Farum, Denmark). 


\subsubsection{Acute toxicity}

Ozonated water samples were subjected to the Microtox (ISO, 2007; Chhetri et al., 2017) toxicity test, which utilises bioluminescent bacteria (Vibrio fischeri) to investigate whether toxic ozonation by-products are formed.

\subsubsection{Data treatment}

Obtained data were analysed using MS Excel and Prism Graph Pad 5.0. Although the systems were identical, they did not cease being autonomous systems hosting living organisms, and they therefore had their own loading and steady state thresholds. It was observed that the zero values (prior to ozonation) for several parameters varied considerably. Thus, normalisation $\left(\mathrm{C} / \mathrm{C}_{0}\right)$ was necessary, to compare better the effect of the different treatments (SI 4.2). However, raw data can be found in SI 4.1.

\subsection{System configuration}

The replicated experimental set-up, located in Hirtshals, Denmark, was designed to mimic commercial RAS. Twelve identical $1.7 \mathrm{~m}^{3}$ pilot-scale RAS (described by Rojas-Tirado et al., 2016) were each stocked with rainbow trout at a density of $40 \mathrm{~kg} / \mathrm{m}^{3} / \mathrm{tank}$ (Funderholme Dambrug, Silkeborg, Denmark). Belt feeders were loaded every morning with a $125 \mathrm{~g}$ feed/system (EFICO Enviro $3 \mathrm{~mm}$; Biomar, Denmark). Water flowed from the rearing tank into the swirl separator $\left(1.5 \mathrm{~m}^{3} / \mathrm{h}\right)$ and then through to the pump sump. From the

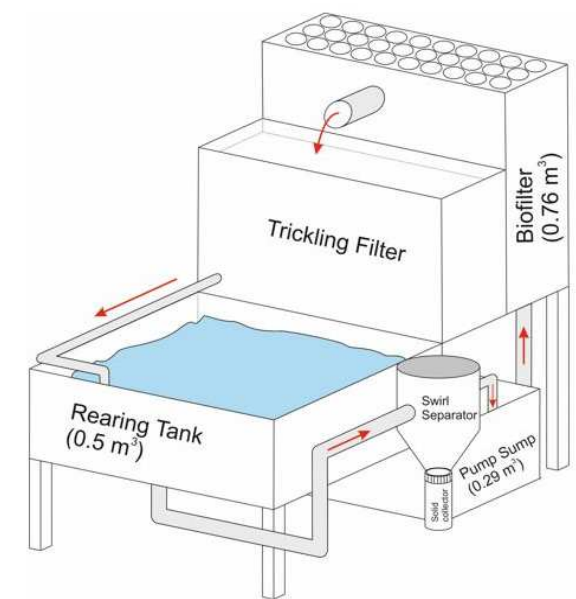

Figure 1: Schematic representation of pilot-scale RAS set-up in Rojas-Tirado et al., 2016. pump sump, water at a flow of $3 \mathrm{~m}^{3} / \mathrm{h}$ was transferred to biofilters. Water excess from the trickling 
filter overflowed back into the pump sump. Biofilters were not backwashed during the experiment, while any settled solids (particulate matter such as any uneaten feed pellets and faeces) were collected in the swirl separator (Fig. 1) and removed daily. Sodium bicarbonate was added to compensate for alkalinity loss due to nitrification, thereby ensuring a relatively stable $\mathrm{pH}$ ranging from 7.4 to 7.5 . Water temperature ranged from 16 to $19^{\circ} \mathrm{C}$ during the trial, while diurnal variations were negligible. The daily photoperiod ranged from 07:30 to 22:00.

\subsection{Experiments}

\subsubsection{Laboratory-scale experiments}

Water samples were collected randomly from one of the twelve RAS during the stabilisation period, kept at $<4^{\circ} \mathrm{C}$ and transported to the laboratory for further analysis. The purpose of the batch experiment was to characterise the water matrix, define the ozone demand, determine the optimal ozone dosage, which ensures improved water quality and its lifetime, and to test ozonation capacity by indicating the critical range in which ozonation can occur safely in such systems.

Several ozone dosage amounts, ranging from 0 to $10 \mathrm{mg} \mathrm{O} / \mathrm{L}$, were spiked in $50 \mathrm{~mL}$ RAS water samples, as described in Hansen et al. (2016), who conducted a similar study in wastewater. To control better ozone concentration in the RAS water samples, the same ozone dosage was added to acidified MilliQ water $(50 \mathrm{~mL})$ containing a $5 \mathrm{~mL}$ phosphate buffer and a sufficient amount of potassium indigotrisulphonate (Antoniou et al., 2013).

To predict optimal ozone dosage in pilot-scale RAS at a given feed loading, water samples were repeatedly ozonated after ozone depletion, to investigate ozone reactivity and its sensitivity to optimal ozone dosage, using the indigo colorimetric assay (Section 2.3.1.1), and to quantify ozone concentration profiles over time, utilising a spectrophotometer. A RAS water sample was divided into five subsamples $(50 \mathrm{~mL}$ each), four of which were ozonated with, for example, $2 \mathrm{mg} / \mathrm{L}$ ozone 
221 ( $1^{\text {st }}$ ozone dosage), while the fifth set was used as a control. In one of the four subsamples, ozone concentration was measured over time. When ozone was depleted, a further dosage was applied (2 $\mathrm{mg} \mathrm{O}_{3} / \mathrm{L} ; 2^{\text {nd }}$ ozone dosage), albeit only for the remaining three samples. Subsequently, ozone concentration was monitored over time in one of the samples. The same procedure was carried out until all the subsamples had been subjected to ozonation. All samples, including the control, were measured with a fluorimeter to define the ozone effect on natural fluorescence degradation (Section 2.3.1.2). Repeated ozonation occurred for every examined ozone dosage.

\subsubsection{Pilot-scale experiments}

The laboratory study was followed by injecting predetermined ozone dosages into pilot-scale RAS (Fig. 2). The pilot-scale investigation lasted 2.5 weeks, and it was divided into three distinct phases. Phase I was the pre-ozonation period (185 days), while Phases II and III represented the two ozonation periods. During Phase II, two replicated trials occurred ( $\mathrm{II}_{\mathrm{A}}$ and $\mathrm{II}_{\mathrm{B}}$ ). In Phase III, $50 \mathrm{~g}$ $\mathrm{O}_{3} / \mathrm{kg}$ of feed, equivalent to twice as much as the highest applied ozone dosage in Phase II, was tested (High $\left.\mathrm{O}_{3} \mathrm{x} 2\right)$. The control values consisted of the average for the three individual systems.

A back-up system remained untouched (operating as described in Section 2.4), to provide fish in case of any mortality. Four RAS were used for each trial, one of which was operated as a reference, where no ozone was added. The three remaining RAS were each equipped with one ozone reaction tank $(18 \mathrm{~L})$ per system. In a side-stream, water was pumped from the swirl separator into the reaction tank at a flow of $0.2 \mathrm{~m}^{3} / \mathrm{h}$ and a retention time of $5.4 \mathrm{~min}$, the remaining water was led to the pump sump (Fig. 2). From the ozone reaction tank, the treated water was also transferred to the pump sump with an overflow, before moving on through biofilters (excess water from the trickling filter returned to the pump sump) and ultimately to the fish tank. In these units, ozone gas, controlled by $6 \mathrm{~mm}$ stainless steel needle valves (to regulate backpressure), was injected (via plastic 

concentrations.

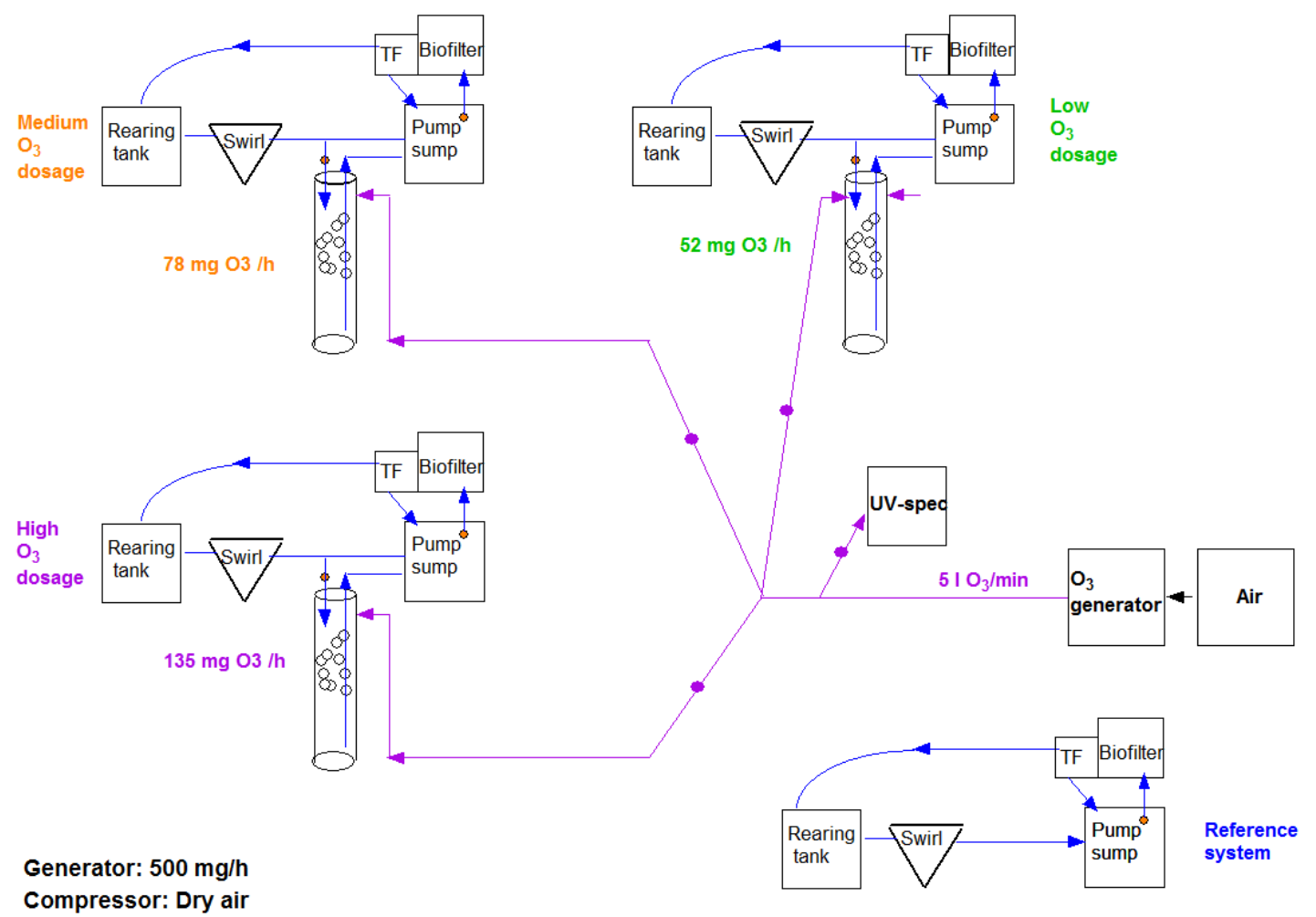

Figure 2: Schematic representation of the four different ozonation-level pilot-scale RAS.

247 Online probes in the rearing tanks continuously recorded DO and REDOX. Oxygen concentration was maintained at $8-8.5 \mathrm{mg} / \mathrm{L}$ via aeration and the addition of pure oxygen with diffusers in the rearing tanks. Fish were inspected and any mortality was noted daily. was measured in the pump sump and rearing tank (Section 2.3.1.2) by the indigo method (Antoniou et al., 2013) and the fluorescence intensity removal method (Spiliotopoulou et al., 2017). Water samples were collected daily from the rearing tank and the pump sumps of the four running units 254 for further analysis.

255 After the first one-week trial (control, low, medium and high $\mathrm{O}_{3}$ ), the experiment was replicated by conducting a similar set of trials in four new units, identical to the previous protocol. These tanks, 
during the first one-week-trial, were handled similarly to the reference tank. Finally, an additional RAS was used to test the high $\mathrm{O}_{3} \times 2$ dosage over a period of three days.

To protect staff from ozone, off-gas from the ozone reaction tanks was vented (through PVC piping) outside the building. Additionally, an ozone gas sensor (Water ApS, Farum, Denmark) was installed in the room to detect ozone gas $\left(<0.14 \mathrm{mg} \mathrm{O}_{3} / \mathrm{L}\right)$ in the surrounding air.

\section{Results and discussion}

The present work was divided into two distinct phases, namely a laboratory and a pilot-scale study. During the laboratory study, water characterisation of the RAS, the effect of ozone on water when organic matter was present, the behaviour of ozone in such water over time and the effect of repeated ozonation in stimulating recirculation were investigated. Analysing these data, we predicted the required ozone dosage for the system and created a dosing range. In the second phase, ozone exposure covering this range was applied in pilot-scale RAS for short experimental periods to validate our hypothesis.

\subsection{Laboratory study}

\subsubsection{Water characterisation}

The water matrix in terms of physicochemical characteristics of the make-up water and nonozonated RAS water were analysed and are presented in SI (Table S2). The make-up water was non-chlorinated groundwater distributed through the municipal system in Hirtshals, Denmark. The inlet water was analysed for all parameters similar to the samples and was found to have no abnormal concentrations, thereby adding no background information to our analyses. Since all RAS were identical, water samples were collected randomly from one system, to determine the water quality baseline during the biofilter stabilisation period. The start-up phase moved on to the 
sampling campaign approximately 1 week after fish were placed in the tanks, while the steady state phase was reached when the biofilter were stable in terms of low TAN and nitrite and elevated stable nitrate (day 70). The $\mathrm{pH}$ during the 70-day period was relatively stable, while a significant increase of $7.9 \mathrm{mg} \mathrm{O}_{2} / \mathrm{L}$ for the NVOC was observed (Table S2), due to fish activity (metabolic byproducts, uneaten feed etc.) and high system intensity. Such high NVOC concentrations, up to 9.7 $\mathrm{mg} / \mathrm{L}$, are often found in commercial trout RAS (Spiliotopoulou et al., 2017).

\subsubsection{Ozone kinetics}

Preliminary ozone experiments were conducted in the laboratory to investigate the ozone effect in organic loaded RAS water. Seven different ozone dosages, ranging from $0.5-10 \mathrm{mg} \mathrm{O}_{3} / \mathrm{L}$, were spiked in RAS water, which was collected over time. The methodology will be described based on the dosage of $10 \mathrm{mg} \mathrm{O}_{3} / \mathrm{L}$ only (Fig. 3), while the remaining results can be found in SI (Fig. S2).

The samples collected during the three sampling campaigns were subjected to ozonation (10 $\mathrm{mg}$ $\mathrm{O}_{3} / \mathrm{L}$ ) and an instant ozone consumption (time $=0 \mathrm{~min}$ ) was observed, which will be referred to herein as "initial ozone demand" (Fig.3). Initial ozone demand increased in line with increasing water pollution: in the make-up water, ozone consumption was $1.3 \mathrm{mg} \mathrm{O}_{3} / \mathrm{L}$ (Fig. 3a), in the start-up phase it was $5.3 \mathrm{mg} \mathrm{O}_{3} / \mathrm{L} \mathrm{(Fig.} \mathrm{3b)} \mathrm{while} \mathrm{in} \mathrm{the} \mathrm{steady} \mathrm{state} \mathrm{it} \mathrm{was} 7.7 \mathrm{mg} \mathrm{O}_{3} / \mathrm{L}$ (Fig. 3c). When water quality deteriorated due to nutrient build-up/accumulation of micro particles, initial ozone demand increased and the ozone lifetimes became shorter. Ozone reacts instantly with easily degradable compounds, resulting in initial ozone demand. Compounds that are more recalcitrant were oxidised by the subsequent ozone cycles.

To investigate the long-term effects of ozone on water, the samples were repeatedly ozonated upon ozone depletion, to simulate recirculation. It is crucial to determine the lifetime of ozone, since it 
304 should not enter the culture tanks or the biofilters. Ozone lifetime in the make-up water (Fig. 3a) 305 was constant between the cycles, suggesting that the make-up water did not contain any organic 306 matter that might react with ozone, and thus its decomposition was extended to more than $130 \mathrm{~min}$. 307 Water from the start-up phase responded differently, since ozone lifetimes varied among the 308 repetitions (Fig. 3b). The first applied dosage degraded fully within $65 \mathrm{~min}$, followed by prolonged 309 cycles up to $100 \mathrm{~min}$, since there was less organic matter present to react with the ozone. Even 310 shorter lifetimes were observed in the highly loaded water (Fig 3c), where the first $10 \mathrm{mg} \mathrm{O}_{3} / \mathrm{L}$ were 311 rapidly consumed $(4 \mathrm{~min})$. The three following ozone spikes/cycles had considerably shorter 312 lifetimes than in the start-up phase and make-up water.

a) Make-up water

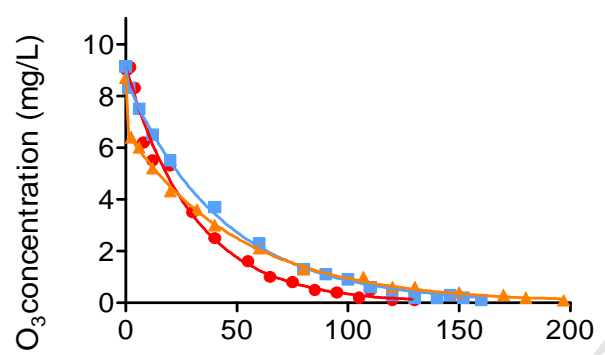

313

314

315 b) Start-up phase

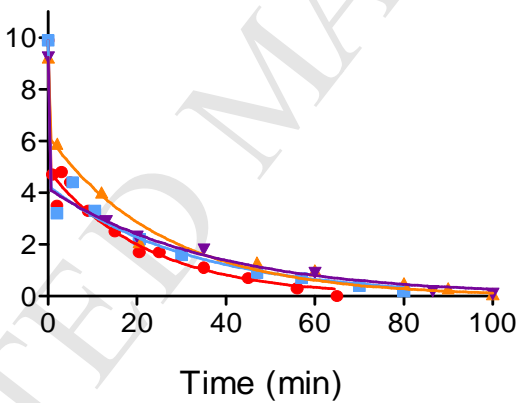

c) Steady-state phase

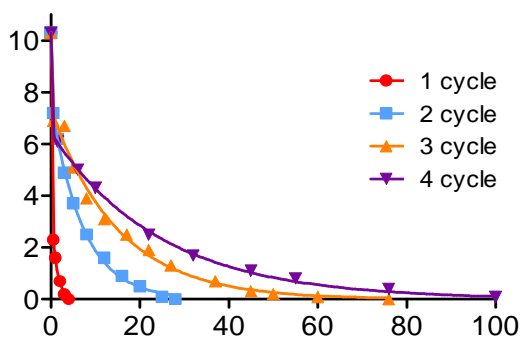

Figure 3: Ozone kinetics of RAS water during 4 consequent dosings (i.e. cycles) in a) make-up water, b) start-up phase and c) steady-state phase. Expected nominal concentrations of ozone was equivalent to $10 \mathrm{mg} \mathrm{O}_{3} / 1$. 


\subsubsection{Fluorescence removal}

317 RAS water contained naturally fluorescent compounds originating mainly from the feed, the inlet water and organic matter produced by the fish and the water treatment process (Hambly et al., 2015). The intensities for both humic and protein-like fluorophores increased as water quality deteriorated (Fig. 4; $0 \mathrm{mg} \mathrm{O}$ / $\mathrm{L}$ ). Similar high fluorescence intensities have been observed in fullscale RAS where trout and eels are farmed (Spiliotopoulou et al., 2017).

a) Make-up water
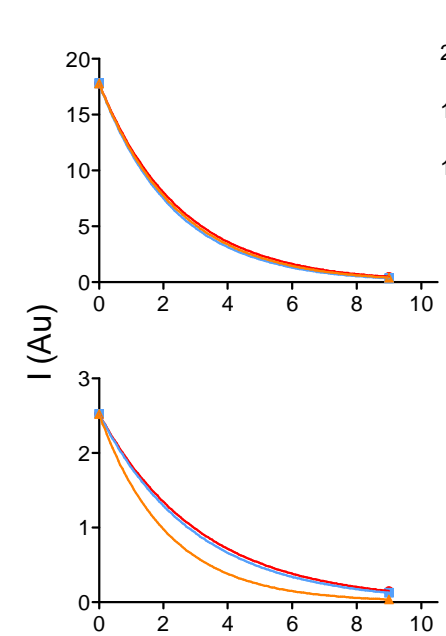

b) Start-up phase

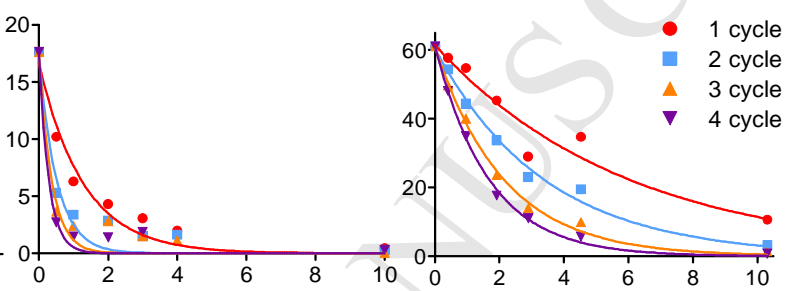

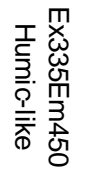

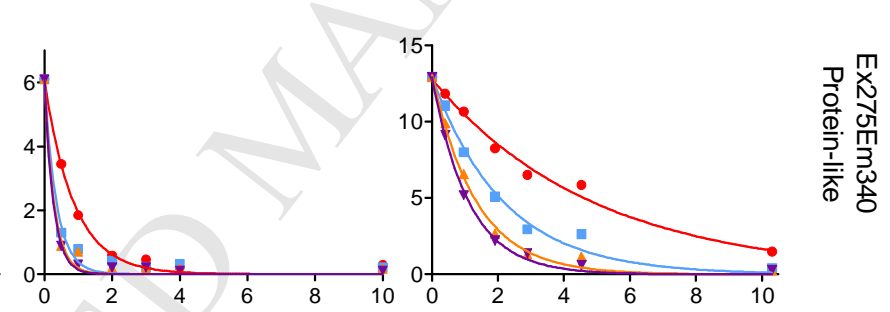

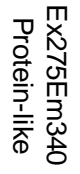

c) Steady-state phase

$\mathrm{O}_{3}$ dosage $(\mathrm{mg} / \mathrm{L})$

Figure 4: Fluorescence degradation of humic and protein-like fluoropores in ozonated RAS water exposed to different ozone levels in a) make-up water, b) start-up phase and c) steady-state phase.

Repeated ozonation did not have any effect on fluorescence, thereby suggesting that a single dosage of 3-4 $\mathrm{mg} \mathrm{O}_{3} / \mathrm{L}$ (approx. $40.8 \mathrm{~g} \mathrm{O}_{3} / \mathrm{kg}$ of feed) was enough to remove the already low fluorescent compounds $(<5 \mathrm{Au})$ from the water. During the start-up phase (prior to ozonation), the initial fluorescence intensity did not change considerably compared to the make-up water (Fig. $4 \mathrm{~b} ; 0 \mathrm{mg}$ $\mathrm{O}_{3} / \mathrm{L}$ ). In terms of humic-like content, intensity was the same as in the make-up water; however, an increase in protein-like fluorophores was observed, possibly due to fish excretions. After ozone addition, all of the fluorophores degraded rapidly; 1-2 $\mathrm{mg} \mathrm{O}_{3} / \mathrm{L} \mathrm{(14-27} \mathrm{g} \mathrm{O}_{3} / \mathrm{kg}$ of feed) was needed 
to decrease fluorescence intensity to $5 \mathrm{Au}$ (Fig. 4b). The first three ozonation cycles overlapped, so they did not have any impact on fluorescence degradation, and only the fourth cycle slightly differed. Thus, mildly polluted water could be treated with a low ozone dosage, since organic matter consists of easily degradable compounds.

In the steady-state samples (Fig. 4c), fluorescence intensity in both wavelength transitions was significantly higher compared to the start-up phase, being in agreement with the NVOC increase over time (Table S2), due to waste accumulation. Fluorescence intensity was highly affected by ozone, and even the lowest ozone dosage reduced it significantly, being in agreement with a previous study that predicted its usability for the sensitive online control of ozone treatment (Spiliotopoulou et al., 2017). Humic-like fluorophores were the most pronounced in this regard, while the protein-like counterparts were lower, albeit still present. After recurrent ozonation, distinct fluorescence removal was observed between the cycles. The higher the ozone dosage, the higher the fluorescence removal.

\subsubsection{Required ozone dosage}

To address ozone demand in a given system, it has been suggested to dose ozone based on feed administered (Bullock et al., 1997; Good et al., 2011) or automatically adjusted to either changes in fish feeding ratio (Summerfelt et al., 2009) or naturally fluorescent organic matter content and degradation (Spiliotopoulou et al., 2017). A wide range of ozone dosages has been reported for RAS, given as either a feed ratio (3-24 $\mathrm{g} \mathrm{O}_{3} / \mathrm{kg}$ of feed; Bullock et al., 1997; Summerfelt et al., 2009), or ORP not exceeding perhaps $300 \mathrm{mV}$ (Bullock et al., 1997). Full-scale ozonation experiments have suggested that improved water quality occurs from 15 to $25 \mathrm{~g} \mathrm{O}_{3} / \mathrm{kg}$ of feed (Summerfelt \& Hochheimer, 1997; Summerfelt et al., 2009; Davidson et al., 2011), though these 
dosages were not used for disinfection but are intended primarily to ameliorate general water quality (Davidson et al., 2011).

The ozone dosage required to satisfy ozone demand might be influenced by feed loading, feed utilisation, water treatment, degree of dilution, etc. in an RAS (Summerfelt et al., 2009). The results presented in Fig. 3 can also be used to interpret the ozone demand of the system based on fish waste production over a 70-day-period. Since the make-up water had no background loading, ozone demand was defined exclusively based on feed input and the associated metabolic excretion. Based on the kinetics for the dosage of $10 \mathrm{mg} \mathrm{O}_{3} / \mathrm{L}$, for instance, we can conclude that ozone demand for the start-up phase water ranges from 15 to $20 \mathrm{mg} \mathrm{O} / \mathrm{L}$. The second, third and fourth cycles overlapped (Fig. 3), meaning that after the second cycle there was no effect of additional dosage; so we conclude that the demand was above $10 \mathrm{mg} \mathrm{O} / \mathrm{L}\left(1^{\text {st }}\right.$ cycle $)$ but less than $20 \mathrm{mg} \mathrm{O} / \mathrm{L}\left(2^{\text {nd }}\right.$ cycle), with each cycle meaning the addition of $10 \mathrm{mg} \mathrm{O}_{3} / \mathrm{L}$. Therefore, it is estimated that ozone demand would be roughly $18 \mathrm{mg} \mathrm{O}_{3} / \mathrm{L}$. For the steady state phase, there was available organic matter to react with ozone until the $3^{\text {d }}$ cycle, and only in the $4^{\text {th }}$ cycle, the kinetics became slower. Thus, we estimated that the ozone demand for this water was between 30 and $40 \mathrm{mg} \mathrm{O}_{3} / \mathrm{L}$.

Ozone demand for the start-up phase was a result of organic matter accumulating over 7 days, while ozone demand for the steady state phase was due to organic matter levels stabilized over 70 days. Based on the results, daily ozone demands (ozone demand/days of waste accumulation) during the start-up and steady state phases were 2.6 and $0.50 \mathrm{mg} / \mathrm{L} / \mathrm{day}$, respectively. By converting daily ozone demand to an hourly rate $(0.1$ and $0.02 \mathrm{mg} / \mathrm{L} / \mathrm{h})$ and multiplying it by the total volume of the system $\left(1.7 \mathrm{~m}^{3}\right)$, we calculated that 182.1 and $35.4 \mathrm{mg} \mathrm{O}_{3} / \mathrm{h}$ were needed to treat water in the two phases, respectively. Subtracting these, $147.7 \mathrm{mg} \mathrm{O} / \mathrm{h}$ was found to be needed to treat the water, corresponding to $28 \mathrm{~g} \mathrm{O}_{3} / \mathrm{kg}$ of feed. A similar dosage was found in Summerfelt et al. (2009). This amount of ozone, if applied on a continuous basis, would purify the water to a great extent. 
Therefore, lower ozone dosages than the calculated (28 $\mathrm{g} \mathrm{O}_{3} / \mathrm{kg}$ of feed) will be applied: 10,15 and $26 \mathrm{~g} \mathrm{O}_{3} / \mathrm{kg}$ of feed, respectively (since, e.g., $26 \mathrm{~g} \mathrm{O}_{3} / \mathrm{kg}$ of feed $* 0.125 \mathrm{Kg}$ of feed $/$ day $=3.3 \mathrm{~g}$ $\mathrm{O}_{3} /$ day $=3.3 * 10^{-3} \mathrm{Kg} \mathrm{O}_{3} /$ day $=135 \mathrm{mg} \mathrm{O}_{3} / \mathrm{h}$, which was less than the $174.7 \mathrm{mg} \mathrm{O}_{3} / \mathrm{h}$ required to purify the water). These dosages were obtained by adding $0.26,0.39$ and $0.68 \mathrm{mg} \mathrm{O}_{3} / \mathrm{L}$ into the ozone reaction tanks (e.g. $3.3 * 10^{-3} \mathrm{Kg} \mathrm{O}_{3} /$ day $* 10^{6} \mathrm{~g} / \mathrm{kg} / 3.33 \mathrm{~L}$ water $/ \mathrm{min} / 1440=0.68 \mathrm{mg} \mathrm{O} / \mathrm{L}$ ). According to previous studies (Summerfelt et al., 2009; Powell \& Scolding, 2016), these concentrations were sufficient to treat the water, still ensuring that no residual ozone could reach neither the rearing tanks, nor the biofilters (Schroeder et al., 2015). The daily ozone dosages required to overcome the demand of an RAS were that low due to continuous water treatment, as the water might go through ozonation up to 50 times per day (Summerfelt et al., 2009). The sufficient retention time of ozone in the systems ensured the absence of residual ozone. A secondary barrier, to compensate for ozone excess, was the side stream design. In the pump sump, ozonated and non-ozonated water was mixed and further diluted by water coming from the trickling filter.

\subsection{Pilot-scale study}

Based on the initial ozone demand of the system, four different ozone dosages, including a reference system (Section 3.1), were applied to pilot-scale RAS to validate if the predicted ozone dosages would improve water in operating RAS and to determine the long-term effects of continuous dosing, if any.

During the first ozonation trial $\left(\mathrm{II}_{\mathrm{A}}\right)$, the set-up and miscellaneous connections were tested to ensure system resilience to ozonation. Unfortunately, ozone delivered at the high dosage (an actual dose of $26 \mathrm{~g} \mathrm{O}_{3} / \mathrm{kg}$ of feed) caused transient leakage from the piping material, and consequently less ozone was delivered to that specific tank than originally envisaged. After this incident, the piping material was changed to PVDF tubing and ozone was delivered properly throughout the following phases 
$404 \mathrm{II}_{\mathrm{B}}$ and III). Therefore, the discussion will be based mainly on results derived from Phases $\mathrm{II}_{\mathrm{B}}$ and 405 III, though all of them will be presented in Fig. 5, which illustrates the sensitivity of various parameters to ozonation.
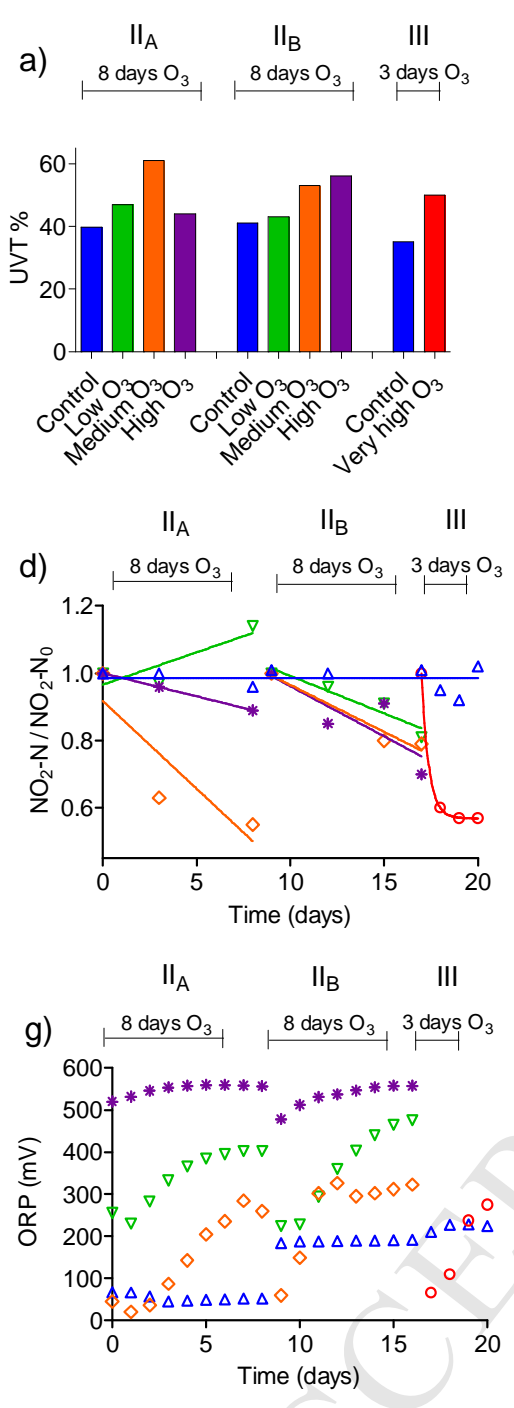

$\begin{array}{llll}\Delta & \text { Controls } & \boldsymbol{\nabla} & \text { Low }_{3}\end{array}$

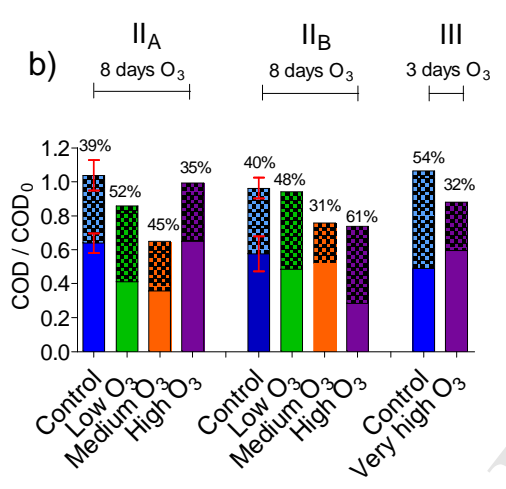

$\mathrm{II}_{\mathrm{A}}$
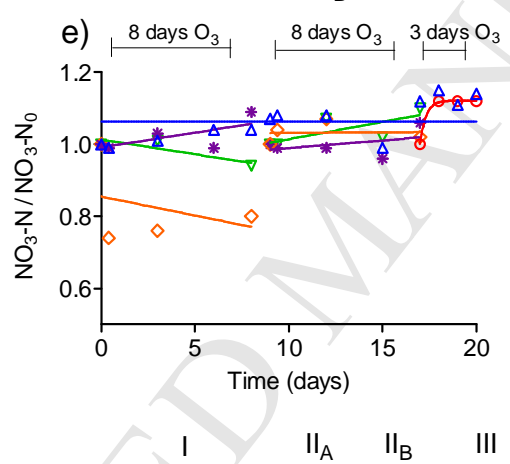

h)

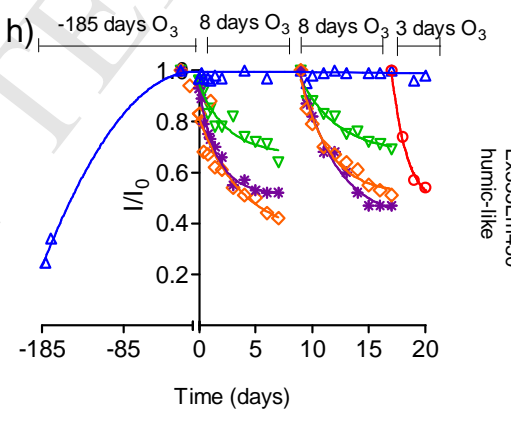

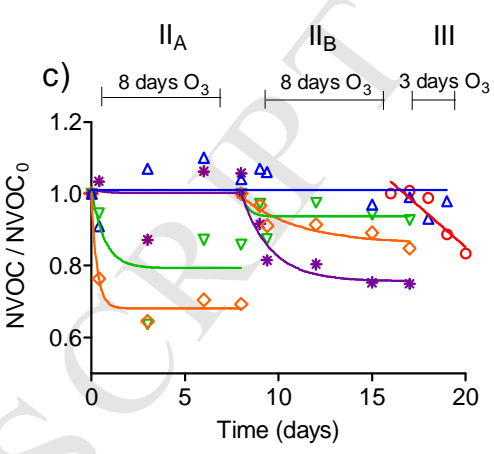

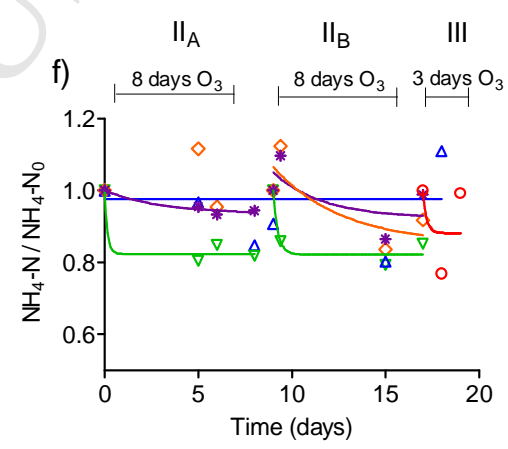

407 408 409 410 411 412
Graphs with raw data can be found in SI. 


\subsubsection{Continuously measured water quality parameters}

Dissolved oxygen and temperature were controlled continuously (Fig. S13). The mean water temperature ranged from $18.0-19.4^{\circ} \mathrm{C}$ during the 2.5 -week trial, with a mean temperature of $18.6^{\circ} \mathrm{C}$. Mean dissolved oxygen was $8.38,8.50,9.02$ and $8.46 \mathrm{mg} / \mathrm{L}$ for the low, medium, high $\mathrm{O}_{3}$ and control treatments, respectively. Assuming that aeration in all RAS was identical, ozone was found to enrich the water with oxygen. Oxygen probes were calibrated at the beginning of each trial.

\subsubsection{Ozone monitoring}

The risk of exposing fish to ozone must be diminished, since it might damage their tissues or gills or even kill them (Powell \& Scolding, 2016). Changes in fish behaviour (feeding and/or swimming) are indicative signs of exposure to toxic concentrations (Bullock et al., 1997). However, during this study, none of these adverse effects was recorded.

Ozone gas was determined on a daily basis, before being injected into the reaction tank (Section 2.3.1.1), and the flows were regulated accordingly, when needed. Water samples were collected from both the pump sump (after ozone) and from the rearing tank, to test for potential ozone presence. By using the indigo method, no ozone residues were detected in any RAS at any time. The absence of residual ozone in the system was expected, due to low ozone dosages and its short lifetime, and ozone was consumed completely within the ozone reaction tank, thereby proving the robustness of the system design. These findings were also supported by toxicity tests. Water samples were collected immediately before ozonation $(0 \mathrm{~h})$ and $6 \mathrm{~h}$ after starting treatment, and they were subjected to microtox analysis. The results indicated no toxicity (less than $20 \%$ inhibition), and so no results will be presented, since it was conclusive that ozone did not have any toxic effect in RAS water. 


\subsubsection{Reduction potential (ORP)}

ORP measurements were made with Oxyguard REDOX probes, in order to acquire a baseline and to facilitate comparison with previous studies. REDOX probes were calibrated at the beginning of each trial. ORP levels can be used to monitor the baseline in a given RAS, and once established, changes in ORP can also be used as an indication of residual ozone build-up (safety measure).

The set point in the present study was at $200 \mathrm{mV}$ (Fig. 5g). Sensors were calibrated a few hours after ozone injection. The REDOX potential in the different systems did not have the same starting point. Essentially, the higher the ORP, the more oxidising agents in the water. Different opinions regarding the ORP set point have been suggested in the literature. Bullock et al. (1997) suggested $300 \mathrm{mV}$ was safe for rainbow trout, while Summerfelt et al. (2009) found that ORP levels up to 340 $\mathrm{mV}$ equalled $0 \mathrm{mg} \mathrm{O}_{3} / \mathrm{L}$. Davidson et al., (2011) suggested a minimum of $250 \mathrm{mV}$ in culture tanks. The OPR level might vary among RAS due to changes in feeding, waste production cycles, oxygen levels and treatment system.

In the present study, the REDOX potential stabilised after 4 days (Phase II), while for the short-term high ozone dosage (Phase III), more time was required to achieve a steady state (Fig. 5g). Based on our findings, adding 10, 15 and $26 \mathrm{~g} \mathrm{O}_{3} / \mathrm{kg}$ of feed, respectively, into the water, increased the REDOX by up to 475,516 and $549 \mathrm{mV}$, respectively. Summerfelt et al. (1997) applied dosages with overlapping ranges, from $24-32 \mathrm{~g} \mathrm{O}_{3} / \mathrm{kg}$ of feed $(28 \pm 4 \mathrm{~g} / \mathrm{kg}, 29 \pm 3 \mathrm{~g} / \mathrm{kg}, 29 \pm 2 \mathrm{~g} / \mathrm{kg})$, achieving various REDOX levels (375, 450 and $525 \mathrm{mV})$. Comparing the highest applied dosage in this study and the derived REDOX with the findings of Summerfelt et al. (1997), the values reported here were higher.

Sensors worked satisfactorily, although ozone is a difficult oxidant to monitor. In an overview study, Li et al. (2014) established that comparing ORP levels across different RAS was difficult, due to different water compositions, system designs, probe specifications and calibration times. 
461 Nonetheless, ORP probes are often used as part of feedback mechanisms to aid in adjusting ozone 462 dosages to the ozone generator (Powell \& Scolding, 2016).

\subsubsection{Fluorescence}

465

Fluorescence has been used widely for monitoring water quality parameters in full-scale applications, in order to optimise processes like aeration (Reynolds \& Ahmad, 1997) and to identify various deteriorating agents of biological (Cumberland et al., 2012) and chemical origin (Baker and Inverarity, 2004; Hudson et al., 2007; Carstea et al., 2016). Hambly et al. (2015) introduced the fluorescence technique in RAS for dissolved organic matter determination, while Spiliotopoulou et al. (2017) suggested a method to correlate fluorescence degradation upon ozonation to the delivered ozone dosage.

Fluorescence is more sensitive to low-ozone level applications such as RAS than ORP probes, as a number of characteristic specific fluorescence compounds exist and can be detected with minimal interference. Water from the pilot RAS was analysed for fluorescent organic matter composition, before ozone implementation (Phase I; Fig. 4) as well as during ozonation (Phases II and III; Fig. 5h, i). Besides the accumulation of organic matter during the first 185 days, the effect of continuous ozonation in different dosages (Section 3.1.3) was depicted (20 days), demonstrating that fluorescence is a suitable method for monitoring organic biomarkers/waste accumulation in RAS. Although water samples were analysed in several wavelength transitions to describe humic and protein-like fluorophores (Fig. S18), only two of them will be discussed herein. Both the humic and the protein-like fluorophores responded alike towards ozone, in that they had the same tendencies as the NVOC. The control reached steady state (day 35 , or the $150^{\text {th }}$ monitoring day) and remained stable until the end of the trial (day 20). 
Significant fluorescent organic matter degradation, in line with increasing ozone dosage, was observed. This decay pattern is in line with the batch experiments (Fig. 4), and also with a recent bench-scale study (Spiliotopoulou et al., 2017). Humic-like compounds oxidised by up to $53 \%$ in the presence of a high dosage, with no significant difference from the medium dosage (Fig. 5h). The high $\mathrm{O}_{3} 2 \mathrm{x}$ dosage resulted in a $46 \%$ reduction during the 3-day treatment. Protein-like fluorophores were reduced by $70 \%$ with more distinct effects among treatments than the humic-like fluorophores (Fig. 5i). The high dosage resulted in the same reduction as for the humic-like fluorophores (43\%). However, the water still contained some fluorophores, which presumably were not reactive to ozone.

Fluorescence was found to describe the accumulation over time reasonably well as the effect of different applied ozone dosages on water quality. During the bench-scale experiment (Fig. 4c), it was predicted that approximately $1 \mathrm{mg} \mathrm{O} / \mathrm{L}$ was required to clarify the water $(20 \mathrm{Au})$, which was

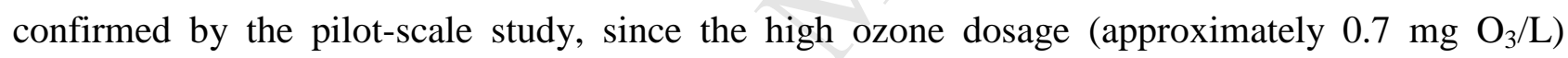
resulted in the same fluorescence removal success (Fig. S2). Therefore, fluorescence could be used as a tool to monitor dissolved ozone in water.

The ozone levels applied in our pilot experiment improved the resulting water quality, albeit not to the extent originally expected. This study differs from other aquaculture studies by investigating mature RAS in steady state conditions (more than three months of constant rearing conditions). The high levels of organic matter were reduced by ozone but at the same time, there was a constant daily organic input via the constant feeding regime. The applied ozone dosages could neither completely eliminate all organic matter nor increase UVT to very high levels, thus leaving future studies to identify the upper threshold for safe ozone application in RAS. 


\subsubsection{Water transparency}

Water samples collected from the pump sump were analysed further, to establish chemical water composition. In a closed system, the water quality is generally the same, independent of sampling location within the system (Rojas-Tirado et al., 2016), which was also confirmed by sampling for residual ozone in several locations throughout the system.

Transmission of UV-light at $254 \mathrm{~nm}$ is a widely used method in both clean and wastewater applications (APHA, 2012). Water transparency is commonly used as an indicator of general water quality and is described by UVA, which represents the amount of light absorbed by particles within a sample. The removal of carbon-based compounds (e.g. NVOC, COD and fluorescent organic matter) resulted in visually cleaner water. UVT is used to define water clarity. In the present study, non-ozonated samples had a UVT of approximately $40 \%$ (Fig. 5a) in agreement with previous studies, typically having UVT values for non-ozonated RAS ranged from 30 to $60 \%$, depending on system intensity (Davidson et al., 2011). The UVT\% of the treated RAS water rose by $15 \%$ compared to the control (Fig. 5a), resulting in 50-60\% UVT\%. For Phases $\mathrm{II}_{\mathrm{B}}$ and $\mathrm{III}$, the same increase in UVT\% was observed, suggesting a correlation between the applied ozone dosage and the treatment period; in Phase III the applied dosage was doubled and the system was ozonated 5 days fewer than in $\mathrm{II}_{\mathrm{B}}$. It can be concluded that the increase in UVT\% was proportional to the treatment period and that ozone boosted UVT (Summerfelt et al., 1997; Christensen et al., 2000; Summerfelt et al., 2009; Davidson et al., 2011), resulting in potential benefits for the fish. Increased visibility can also improve UV treatment efficacy and several water treatment processes within the unit. 


\subsubsection{Organic matter}

Ozone is a highly reactive agent rapidly oxidising organic matter and contaminants (Summerfelt et al., 1997; Good et al., 2011). At the beginning of Phase I (Table S2), the NVOC was $3.1 \mathrm{mg} / \mathrm{L}$, while at the end of the phase it had been elevated to $9.7 \mathrm{mg} / \mathrm{L}$ (approximately day 70 ). From that point onwards, and until Phase II (day 181), the NVOC was relatively stable (Table S2). However, upon ozonation, NVOC concentration diminished (Fig. 5c) dosage dependently, up to 25\% (high dosage, $\mathrm{II}_{\mathrm{B}}$ ); while in the high $\mathrm{O}_{3} \times 2$ dosage (III) the decrease was $17 \%$. In the latest phase, NVOC reduction was proportional to ozone exposure, while in Phase $\mathrm{II}_{\mathrm{B}}$ a rapid decrease was observed within the first exposure days, following which removal intensity was smoother, albeit present (first-order decay).

A supplementary parameter to quantify oxidisable organic matter in water is the COD. The dissolved fraction was the dominant (Fig. 5b). However, due to short-term treatment, the effect of ozone on COD was not clear and there was variability in the control samples (standard deviation in control samples; Fig. 5b).

\subsubsection{Nitrogen-based compounds}

Nitrite is toxic to cultivated organisms in RAS (Kroupova et al., 2005; Svobodová et al., 2005), and therefore proper nitrification is vital for oxidising nitrite into harmless nitrate. Nitrite-N concentration was approximately $0.06 \mathrm{mg} \mathrm{N} / \mathrm{L}$ (Fig. S9), which was relatively low compared to previous studies (Pedersen et al., 2012). $\mathrm{NO}_{2}{ }^{-}-\mathrm{N}$ removal was approximately 20\%, without a significant difference between ozone dosages (Fig. 5d) - in line with previous studies (Summerfelt et al., 1997; Davidson et al., 2011). The 2x high-ozone dosages removed more than $40 \%$ of the system's nitrite, reacting rapidly at the beginning of the treatment and reaching a new steady state in the ensuing days. 
$551 \mathrm{NO}_{3}{ }^{-} \mathrm{N}$ concentrations were unaffected by ozonation (Fig. 5e), since ozone does not react with 552 nitrate, and the filters were operating properly during the experimental period. The nitrate-N level 553 was approximately $60 \mathrm{mg} \mathrm{N} / \mathrm{L}$ (Fig. S12), which is comparable to previous studies performing in 554 similar conditions (Pedersen et al., 2012; Fernandes et a., 2015).

555 Concentrations of total $\mathrm{NH}_{4}{ }^{+}-\mathrm{N} / \mathrm{NH}_{3}-\mathrm{N}$ (TAN) during ozonation were low (0.10 to $\left.0.18 \mathrm{mg} \mathrm{N} / \mathrm{L}\right)$ 556 and not strictly related to ozone dosage (Fig. 5f) as previously found by Davidson et al. (2011). 557 Ammonia is not readily oxidised by ozone (Timmons et al., 2002), unless pH levels are 9 or above 558 (Rice et al., 1981).

4. Conclusions

561 Ozonation for all test dosages generally resulted improved water quality. Compared to the unexposed RAS control, treated water in RAS exposed to medium- and high-ozone dosages saw a reduction in organic compounds of up to $53 \%$ and $70 \%$ reductions in humic and protein-like fluorophores, respectively. During the 20 days of ozone exposure, no fish mortality occurred, ozonation improved UVT by $30 \%$ and no toxic ozonated by-products were formed or detected.

By testing individual water samples from a RAS, laboratory tests can be used to predict the ozone demand for the specific system, thus improving treatment efficacy. The main conclusions are summarised thus:

- Bench-scale experiments can predict the effect of continuous ozonation in pilot-scale RAS.

- Fluorescence describes well the build-up and removal of organic matter caused by fish in an RAS.

- Thus, fluorescence can potentially serve as an online measurement to control water quality. 
573

574

575

\section{Acknowledgements}

The authors wish to acknowledge Innovation Fund Denmark, OxyGuard International A/S and Water ApS for funding the $\mathrm{PhD}$ stipend for A. Spiliotopoulou. The authors are grateful to the laboratory staff at DTU Environment and DTU Aqua for assisting in analysing samples, with the latter also thanked for providing the facilities in Hirtshals.

\section{Reference list}

Antoniou, M. G., Hey, G., Rodríguez Vega, S., Spiliotopoulou, A., Fick, J., Tysklind, M., Jensen, J., Andersen, H. R. (2013). Required ozone doses for removing pharmaceuticals from wastewater effluents. Science of The Total Environment, 456-457, 42-49. http://doi.org/10.1016/j.scitotenv.2013.03.072

APHA. (2012). Standard Methods for the Examination of water and wastewater (22nd editi). Washington DC, USA: American Public Health Association/American Water Works Association/Water Environment Federation.

Bader, H., \& Hoigné, J. (1981). Determination of ozone in water by the indigo method. Water Research. http://doi.org/10.1016/0043-1354(81)90054-3

Bahr, C., Schumacher, J., Ernst, M., Luck, F., Heinzmann, B., \& Jekel, M. (2007). SUVA as control parameter for the effective ozonation of organic pollutants in secondary effluent. In Water Science and Technology. http://doi.org/10.2166/wst.2007.418

Bullock, G. L., Summerfelt, S. T., Noble, A. C., Weber, A. L., Durant, M. D., \& Hankins, J. A. (1997). Ozonation of a recirculating rainbow trout culture system. I. Effects on bacterial gill disease and heterotrophic bacteria. Aquaculture. http://doi.org/10.1016/S0044-8486(97)00063-X

Chhetri, R.K., Baun, A., Andersen, H. R. (2017). Acute toxicity and risk evaluation of the CSO disinfectants performic acid, peracetic acid, chlorine dioxide and their by-products hydrogen peroxide and chlorite. Water Research.

Cumberland, S., Bridgeman, J., Baker, A., Sterling, M. (2012). Fluorescence spectroscopy as a tool for 
determining microbial quality in potable water applications, 3330(July 2016). http://doi.org/10.1080/09593330.2011.588401

Davidson, J., Good, C., Welsh, C., \& Summerfelt, S. (2011). The effects of ozone and water exchange rates on water quality and rainbow trout Oncorhynchus mykiss performance in replicated water recirculating systems. Aquacultural Engineering. http://doi.org/10.1016/j.aquaeng.2011.04.001

Fernandes, P., Pedersen, L.-F., \& Pedersen, P. B. (2015). Microscreen effects on water quality in replicated recirculating aquaculture systems. Aquacultural Engineering, 65, 17-26. http://doi.org/10.1016/j.aquaeng.2014.10.007

Good, C., Davidson, J., Welsh, C., Snekvik, K., \& Summerfelt, S. (2011). The effects of ozonation on performance, health and welfare of rainbow trout Oncorhynchus mykiss in low-exchange water recirculation aquaculture systems. Aquacultural Engineering. http://doi.org/10.1016/j.aquaeng.2011.04.003

Hambly, A. C., Arvin, E., Pedersen, L. F., Pedersen, P. B., Seredynska-Sobecka, B., \& Stedmon, C. A. (2015). Characterising organic matter in recirculating aquaculture systems with fluorescence EEM spectroscopy. Water Research, 83, 112-120. http://doi.org/10.1016/j.watres.2015.06.037

Hansen, K. M. S., Spiliotopoulou, A., Cheema, W. A., \& Andersen, H. R. (2016). Effect of ozonation of swimming pool water on formation of volatile disinfection by-products - A laboratory study. Chemical Engineering Journal. http://doi.org/10.1016/j.cej.2015.12.052

Hansen, K. M. S., Spiliotopoulou, A., Chhetri, R. K., Escolà Casas, M., Bester, K., \& Andersen, H. R. (2016). Ozonation for source treatment of pharmaceuticals in hospital wastewater - Ozone lifetime and required ozone dose. Chemical Engineering Journal. http://doi.org/10.1016/j.cej.2016.01.027

Hansen, K. M. S., Andersen, H. R., \& Ledin, A. (2010). Ozonation of estrogenic chemicals in biologically treated sewage. Water Science and Technology, 62(3), 649-657. http://doi.org/10.2166/wst.2010.919

Hohreiter, D. W., \& Rigg, D. K. (2001). Derivation of ambient water quality criteria for formaldehyde. Chemosphere, 45(4-5), 471-486. http://doi.org/10.1016/S0045-6535(01)00061-3

Hudson, Naomi; Baker, Andy; Reynolds, D. (2007). Fluorescence analysis of dissolved organic matter in natural, waste and polluted waters-a review. River Research and Applications, 23(April), 631-649. 
http://doi.org/10.1002/rra

ISO. (2007). No TitleWater quality -- Determination of the inhibitory effect of water samples on the light emission of Vibrio fischeri (Luminescent bacteria test) -- Part 3: Method using freeze-dried bacteria. Retrieved from http://www.iso.org/iso/iso_catalogue/catalogue_tc/catalogue_detail.htm?csnumber=40518 (accessed 5.26.16)

Kroupova, H., Machova, J., \& Svobodova, Z. (2005). Nitrite influence on fish: A review. Veterinarni Medicina, 50(11), 461-471.

Li, X., Blancheton, J.-P., Liu, Y., Triplet, S., \& Michaud, L. (2014). Effect of oxidation-reduction potential on performance of European sea bass (Dicentrarchus labrax) in recirculating aquaculture systems. Aquaculture International, 22(4), 1263-1282. http://doi.org/10.1007/s10499-013-9745-3

Masters. (2004). A Review of Methods for Detoxification and Neutralization of Formalin in Water, 66(January), 325-333.

Muller, P. Y., \& Milton, M. N. (2012). The determination and interpretation of the therapeutic index in drug development. Nature Reviews Drug Discovery, 11(10), 751-761. http://doi.org/10.1038/nrd3801

Nanaboina, V., \& Korshin, G. V. (2010). Evolution of absorbance spectra of ozonated wastewater and its relationship with the degradation of trace-level organic species. Environmental Science and Technology, 44(16), 6130-6137. http://doi.org/10.1021/es1005175

Noble, A. C., \& Summerfelt, S. T. (1996). Disease enciyntered in rainbow trout cultured in recirculating systems. Pergamon Annual Review of Fish Diseases, 6, 65-92.

Pedersen, L. F., Meinelt, T., \& Straus, D. L. (2013). Peracetic acid degradation in freshwater aquaculture systems and possible practical implications. Aquacultural Engineering, 53, 65-71. http://doi.org/10.1016/j.aquaeng.2012.11.011

Pedersen, L. F., \& Pedersen, P. B. (2012). Hydrogen peroxide application to a commercial recirculating aquaculture system. Aquacultural Engineering, 46(1), 40-46. http://doi.org/10.1016/j.aquaeng.2011.11.001

Pedersen, L. F., Pedersen, P. B., Nielsen, J. L., \& Nielsen, P. H. (2010). Long term/low dose formalin 
653

exposure to small-scale recirculation aquaculture systems. Aquacultural Engineering, 42(1), 1-7. http://doi.org/10.1016/j.aquaeng.2009.08.002

Pedersen, L. F., Suhr, K. I., Dalsgaard, J., Pedersen, P. B., \& Arvin, E. (2012). Effects of feed loading on nitrogen balances and fish performance in replicated recirculating aquaculture systems. Aquaculture, 338-341, 237-245. http://doi.org/10.1016/j.aquaculture.2012.01.035

Piedrahita, R. H. (2003). Reducing the potential environmental impact of tank aquaculture effluents through intensification and recirculation. Aquaculture, 226(1-4), 35-44. http://doi.org/10.1016/S00448486(03)00465-4

Powell, A., \& Scolding, J. W. S. (2016). Direct application of ozone in aquaculture systems, 1-15. http://doi.org/10.1111/raq.12169

Reynolds, D. M., \& Ahmad, S. R. (1997). Rapid and direct determination of wastewater BOD values using a fluorescence technique. Water Research, 31(8), 2012-2018. http://doi.org/10.1016/S00431354(97)00015-8

Rice, R.G., Robson, C.M., Miller, G.W., Hill, A. G. (1981). Uses of ozone in drinking water treatment. Am.Water Works Assoc. J., 73, 1-44.

Rojas-Tirado, P., Pedersen, P. B., \& Pedersen, L.-F. (2016). Bacterial activity dynamics in the water phase during start-up of recirculating aquaculture systems. Aquacultural Engineering. http://doi.org/10.1016/j.aquaeng.2016.09.004

Schroeder, J. P., Klatt, S. F., Schlachter, M., Zablotski, Y., Keuter, S., Spieck, E., \& Schulz, C. (2015). Impact of ozonation and residual ozone-produced oxidants on the nitrification performance of movingbed biofilters from marine recirculating aquaculture systems. Aquacultural Engineering. http://doi.org/10.1016/j.aquaeng.2014.10.008

Spiliotopoulou, A., Martin, R., Pedersen, L. F., \& Andersen, H. R. (2017). Use of fluorescence spectroscopy to control ozone dosage in recirculating aquaculture systems. Water Research, 111, 357-365. http://doi.org/10.1016/j.watres.2016.12.036

Summerfelt, S. T., Hankins, J. A., Weber, A. L., Durant, M. D., \& Virginia, W. (1997). Effects of ozone on microscreen firtration and water quality in a recirculating rainbow trout culture system, 158, 1-12. 
680

681

682

683

684

685

686

687

688

689

690

691

692

693

694

695

696

697

698

699

700

701

702

703

704

705

706

Summerfelt, S. T., \& Hochheimer, J. N. (1997). Review of Ozone Processes and Applications as an Oxidizing Agent in Aquaculture. The Progressive Fish-Culturist, 59(2), 94-105. http://doi.org/10.1577/1548-8640(1997)059<0094:ROOPAA>2.3.CO;2

Summerfelt, S. T., Sharrer, M. J., Hollis, J., Gleason, L. E., \& Summerfelt, S. R. (2004). Dissolved ozone destruction using ultraviolet irradiation in a recirculating salmonid culture system. In Aquacultural Engineering. http://doi.org/10.1016/j.aquaeng.2004.06.004

Summerfelt, S. T., Sharrer, M. J., Tsukuda, S. M., \& Gearheart, M. (2009). Process requirements for achieving full-flow disinfection of recirculating water using ozonation and UV irradiation. Aquacultural Engineering. http://doi.org/10.1016/j.aquaeng.2008.10.002

Svobodová, Z., Máchová, J., Poleszczuk, G., Hůda, J., Hamáčková, J., \& Kroupová, H. (2005). Nitrite poisoning of fish in aquaculture facilities with water-recirculating systems. Acta Veterinaria Brno, 74(1), 129-137. http://doi.org/10.2754/avb200574010129

Tango, M. S., \& Gagnon, G. A. (2003). Impact of ozonation on water quality in marine recirculation systems. Aquacultural Engineering, 29(3-4), 125-137. http://doi.org/10.1016/S0144-8609(03)00061-X

Timmons, M.B., Ebeling, J.M., Wheaton, F.W., Summerfelt, S.T., Vinci, B. J. (2002). Recirculating Aquaculture Systems (2nd Ed.). NY, USA.: Cayuga Aqua Ventures, Ithaca.

Tsolaki, E., \& Diamadopoulos, E. (2010). Technologies for ballast water treatment: A review. Journal of Chemical Technology and Biotechnology, 85(1), 19-32. http://doi.org/10.1002/jctb.2276

Verner-Jeffreys, D. (n.d.). SARF 100 -Review of freshwater treatments used in the Scottish freshwater rainbow trout aquaculture industry. A report commissioned by sarf and prepared by.

Von Gunten, U. (2003). Ozonation of drinking water: Part I. Oxidation kinetics and product formation. Water Research, 37(7), 1443-1467. http://doi.org/10.1016/S0043-1354(02)00457-8

Wenk, J., Aeschbacher, M., Salhi, E., Canonica, S., Von Gunten, U., \& Sander, M. (2013). Chemical oxidation of dissolved organic matter by chlorine dioxide, chlorine, and ozone: Effects on its optical and antioxidant properties. Environmental Science and Technology, 47(19), 11147-11156. http://doi.org/10.1021/es402516b

Wooster, G., Martinez, C., Bowser, P., \& O’Hara, D. (2005). Human Health Risks Associated with Formalin 


\section{Highlights}

- Bench-scale experiments predicted continuous ozonation in pilot-scale RAS

- Fluorescence describes the waste build-up caused by fish and the removal by ozone

- Ozone lifetime decreases with organic loading and increases with continued ozonation

- Ozone degraded organic matter and thus improved ORP and transparency

- Ozone by-products and toxicity are not found in freshwater RASs. 